\title{
Antibiotic Resistant Superbugs: Assessment of the Interrelationship of Occurrence in Clinical Settings and Environmental Niches
}

\author{
Anthony Ayodeji Adegoke 1,2,3,*, Adekunle Christopher Faleye ${ }^{1}$, Gulshan Singh ${ }^{1}$ \\ and Thor Axel Stenström ${ }^{1}$ \\ 1 SARChI, Institute for Water and Wastewater Technology, Durban University of Technology, Durban 4000, \\ South Africa; kunle_faleye@yahoo.co.uk (A.C.F.); gsingh.gulshan@gmail.com (G.S.); thors@dut.ac.za (T.A.S.) \\ 2 Department of Microbiology, University of Uyo, 520211 Uyo, Akwa Ibom State, Nigeria \\ 3 Department of Biochemistry and Microbiology, University of Fort Hare, Alice 5700, Eastern Cape, South Africa \\ * Correspondence: anthonya1@dut.ac.za or aayodegoke@gmail.com or aadegoke@ufh.ac.za; \\ Tel.: +27-60-407-3200
}

Academic Editor: Peter J. Rutledge

Received: 4 November 2016; Accepted: 22 December 2016; Published: 27 December 2016

\begin{abstract}
The increasing threat to global health posed by antibiotic resistance remains of serious concern. Human health remains at higher risk due to several reported therapeutic failures to many life threatening drug resistant microbial infections. The resultant effects have been prolonged hospital stay, higher cost of alternative therapy, increased mortality, etc. This opinionated review considers the two main concerns in integrated human health risk assessment (i.e., residual antibiotics and antibiotic resistant genes) in various compartments of human environment, as well as clinical dynamics associated with the development and transfer of antibiotic resistance (AR). Contributions of quorum sensing, biofilms, enzyme production, and small colony variants in bacteria, among other factors in soil, water, animal farm and clinical settings were also considered. Every potential factor in environmental and clinical settings that brings about AR needs to be identified for the summative effects in overall resistance. There is a need to embrace coordinated multi-locational approaches and interrelationships to track the emergence of resistance in different niches in soil and water versus the hospital environment. The further integration with advocacy, legislation, enforcement, technological innovations and further research input and recourse to WHO guidelines on antibiotic policy would be advantageous towards addressing the emergence of antibiotic resistant superbugs.
\end{abstract}

Keywords: residual antibiotics; antimicrobial resistance; total antibiotic resistance; critical control point; superbug; exposure; health risk assessment

\section{Introduction}

The emergence of antibiotic resistance (AR) is an outcome of a repertoire of factors in various environmental and clinical settings. Rizzo et al. [1] described wastewater treatment plants (WWTPs) as the hotspots for the emergence of AR. Additionally surface water and soil have equally been reported by several authors to harbour AR-inducing factors [1-8]. The critical role of the environment in the development and dissemination of antibiotic resistance genes (ARGs) is fast being appreciated, unlike the time when all focus was on hospital-acquired AR. Antibiotics and ARGs may partly originate from environmental bacteria, and selection for them is closely connected with anthropogenic contamination with residual antibiotics (RAbs), to which exposure of pathogenic bacteria in the same environment occurs [9]. Water environments are one of several platforms for the circulation and accumulation of discharged antibiotics and are recognized for dissemination of ARGs [10]. ARGs in water environments correlate with human activities that involve antibiotic usage [11-13]. The concentration of RAbs in 
the environment usually correlates with that of ARGs [14,15]. Antibiotic usage and/or abuse in human and veterinary medicine, and the pharmaceutical industries as well as their release with human and animal wastes are closely connected with increased prevalence of antimicrobial-resistant bacteria (AMRB) [16,17]. A sub-lethal concentration of antibiotic (or sub MIC) selects for resistant bacteria in any setting [18]. It is therefore imperative to harmonize various factors that bring about the exposure of bacteria to the sub-lethal or sub-inhibitory concentration of the antibiotics beyond the clinical settings, in line with WHO global action against AR [19]. Without any doubt, the origin and spread of antimicrobial resistance (AMR) is a very complex problem that is predicated by multifaceted contributing factors and requires multidisciplinary solutions $[20,21]$. This review will identify several factors in the environment involving wastewater, surface water, soil and important clinical or patient dependent factors and their interrelationship in contributing to AMR, as well as a possible novel approach to address it.

\section{The Soil Resistome as a Contributor to AMR}

Several antibiotics originate from bacteria and/or fungi from soil [2,22] as metabolites for outcompeting other organisms in the same niche, since competition among microorganisms is natural. From the history of antibiotics, the knowledge of these antagonistic interactions brought about the discovery of antibiotics $[5,23,24]$. This paved the way for the first major success in human struggle with infectious diseases, with an appreciable reduction in death worldwide [25,26]. No sooner was this success achieved than the observation of resistance to the first antibiotic, penicillin, was reported [27]. Similarly, the emergence of resistance has been repeatedly shown with each antibiotic subsequently discovered or developed [23].

Earlier, AR was defined in the light of increased MICs with no regard to microbial intrinsic ability to resist them [28] nor the potentials of the microbe to harbour ARGs, acquired vertically or horizontally. In addition the natural ability of antibiotic producers to resist their own metabolites (antibiotics) [5,29], it is now a known fact that various niches in the environment promote the emergence of AR as they contain pools of genes similar to ARGs in the hospital [30]. Antibiotic- producing bacteria which are known for resistance to their own antibiotics have inherent potentials or genes, some of which may be lost by them and gained by other bacteria in the same niche. The loss and gain in this respect may be supported by external stress in the soil microbiota. This is exemplified by the loss of plasmids by Bacillus subtilis due to interaction with B. simplex [31]. Various soil microbiota therefore are critical niches for the emergence and dissemination of ARGs with direct or indirect effect on the clinical isolates and therapeutic outcome on infectious diseases [6,7]. The soil thus becomes very significant because of reports of novel ARGs [30-32].

Factors enhancing the continued persistence of ARGs and AMR in soil include the use of organic fertilizers or manure containing RAbs, ARGs, AMRB, etc. [33]. The RAbs found in organic fertilizers originate from human activities. Organic fertilizer was in one instance shown to contribute as much as $20 \mathrm{mg} \cdot \mathrm{kg}^{-1}$ of tetracycline to the soil, exposing the soil bacteria to sub-lethal concentrations with resistance as a consequence [34] and selection for antibiotic resistance genes which end up being released in the soil. The administration of the antibiotics for either therapeutic and prophylactic purposes in clinical settings as well as in livestock at $<0.2 \mathrm{~g} \cdot \mathrm{kg}^{-1}$ to improve feed efficiency and growth rates [21,35] stands as the major contributing factor. The Alliance for Prudent Use of Antibiotics (APUA) emphasizes the huge impact of antibiotic administration in animal husbandry resulting in the overall rise in AR globally [36]. In America, up to 200,000 tons of antibiotics are used annually combined by humans and administered to farm animals [37]. This also includes antibiotic use in plant agriculture [38]. Table 1 provides a summary of the reported release of some RAbs as well as exemplifying some of the ARGs in soil, aquatic biomes and other related strata of the environment.

It is noteworthy that each time swine manure was applied to the soil, Pan et al. [39] reported that $0.001-29 \mathrm{mg} \cdot \mathrm{kg}^{-1}$ of sulfonamides, $0.03-765 \mathrm{mg} \cdot \mathrm{kg}^{-1}$ of tetracycline, and $0.05-0.11 \mathrm{mg} \cdot \mathrm{kg}^{-1}$ macrolide were also released to the soil, as the manure contained them. This is closely linked to high induction of 
AR in soil, as well as the corresponding proportion of ARGs [40], making it critical to track and stop the emergence of resistance. The impact of emerging resistance in the soil would be appreciated by reconciling the deposit with the way microorganisms are recycled between hospital and environment. Despite this, the numbers of studies relating to tracking ARGs in the environment are limited. Most of the existing studies are limited to cultured microorganisms and with a focus on a few common resistance genes. Furthermore it is mainly guided by clinical reports with little or no reference to the environment. Accurate data on the ARGs as well as projection for potential AMRB in the environment could be acquired, if researchers designed such enumeration towards the uncultured microorganisms that constitute the majority in the environment [41].

Table 1. Reported sub-lethal concentrations of residual antibiotics (RAbs) and antibiotic resistance genes (ARGs) in soil, aquatic environments and other related strata of the environment.

\begin{tabular}{|c|c|c|c|c|c|}
\hline Environment & Source & RAb/ARGs & Reported Concentration & Country & References \\
\hline \multirow{15}{*}{ Soil } & \multirow{5}{*}{ Soil } & CIP & $2.77 \mu \mathrm{g} / \mathrm{kg}$ & \multirow{5}{*}{ Pakistan } & \multirow{5}{*}{ [42] } \\
\hline & & OFL & $2.98 \mu \mathrm{g} / \mathrm{kg}$ & & \\
\hline & & LEV & $3.35 \mu \mathrm{g} / \mathrm{kg}$ & & \\
\hline & & OXT & $4.53 \mu \mathrm{g} / \mathrm{kg}$ & & \\
\hline & & DOX & $3.12 \mu \mathrm{g} / \mathrm{kg}$ & & \\
\hline & \multirow{6}{*}{ Grape soil } & Sul 1 & $(39.19 \pm 0.77) \times 10^{-2}$ & \multirow{6}{*}{ China } & \multirow{6}{*}{ [43] } \\
\hline & & sulII & $(0.42 \pm 0.08) \times 10^{-3}$ & & \\
\hline & & sulIII & $(0.48 \pm 0.10) \times 10^{-3}$ & & \\
\hline & & tet $A$ & $(0.02 \pm 0.00) \times 10^{-3}$ & & \\
\hline & & tetB & $(0.44 \pm 0.07) \times 10^{-3}$ & & \\
\hline & & tet $O$ & $(10.55 \pm 1.23) \times 10^{-2}$ & & \\
\hline & \multirow{2}{*}{ Soil } & SMT & $0.01 \mu \mathrm{g} / \mathrm{g}$ & \multirow{2}{*}{ China } & \multirow{2}{*}{ [43] } \\
\hline & & OTC & $0.02 \mu \mathrm{g} / \mathrm{g}$ & & \\
\hline & Vegetable soil & TET & $8400 \mu \mathrm{g} / \mathrm{kg}$ & China & [44] \\
\hline & Animal manure & BAC & $0.01-1.76 \mathrm{mg} / \mathrm{kg}$ & Canada & [45] \\
\hline \multirow{14}{*}{$\begin{array}{c}\text { Aquatic } \\
\text { Environment }\end{array}$} & \multirow{9}{*}{ Wastewater } & CIP & $3.0-5.25 \mathrm{mg} / \mathrm{L}$ & \multirow{5}{*}{ Pakistan } & \multirow{5}{*}[42]{} \\
\hline & & LEV & $0-6.20 \mathrm{mg} / \mathrm{L}$ & & \\
\hline & & OFL & $2.45-4.12 \mathrm{mg} / \mathrm{L}$ & & \\
\hline & & OTC & $0-9.40 \mathrm{mg} / \mathrm{L}$ & & \\
\hline & & DOX & $1.58-6.75 \mathrm{mg} / \mathrm{L}$ & & \\
\hline & & AMX & $6.94 \mu \mathrm{g} / \mathrm{L}$ & Australia & [46] \\
\hline & & CIP & $0.72 \mu \mathrm{g} / \mathrm{L}$ & Hong Kong & [47] \\
\hline & & OFL & $0.60 \mu \mathrm{g} / \mathrm{L}$ & Italy & [48] \\
\hline & & ERY & $2.5-6.0 \mu \mathrm{g} / \mathrm{L}$ & Germany & [49] \\
\hline & Surface water & OFL & $0.31 \mu \mathrm{g} / \mathrm{L}$ & Italy & {$[48,50]$} \\
\hline & \multirow{4}{*}{ Hospital effluents } & AMX & $35.12 \mu \mathrm{g} / \mathrm{L}$ & \multirow{4}{*}{ Brazil } & \multirow{4}{*}{ [51] } \\
\hline & & AMP & $389.13 \mu \mathrm{g} / \mathrm{L}$ & & \\
\hline & & CFX & $300.1 \mu \mathrm{g} / \mathrm{L}$ & & \\
\hline & & PEN G & $434.46 \mu \mathrm{g} / \mathrm{L}$ & & \\
\hline
\end{tabular}

Key: AMX = Amoxicillin; BAC = Bacitracin; CFX = Cefotaxime; CIP = Ciprofloxacin; DOX = Doxytetracycline; ERY = Erythromycin; LEV = Levofloxacin; OTC = Oxytetracycline; OFL = Ofloxacin; PEN G = Penicillin G; SMT $=$ Sulphamethaxazole; TET $=$ Tetracycline .

Since ARGs reside in both cultured and uncultured bacteria, studies should consider research approaches using direct detection to determine the total ARGs in the environment. Similarly, more accurate detection of organisms exemplifies more accurate detection of total ARGs in the same microbiota. Several uncultured microorganisms harbour biotechnologically and public health important genes [23]. The use of direct detection (culture-free) techniques that account for uncultured bacteria in tracking the distribution of ARGs within the surface water environment is hereby advocated. As stated earlier, this will provide more effective insight into actual distribution of the total ARGs within the microbiota [17,23]. It also gives room for detection of novel ARGs in the study environment [17]. 
This is exemplified by Cheng et al. [17] reports that showed the usefulness of functional metagenomics in identifying new ARGs. Nesme et al. [30] studied antibiotic resistance in the environment more effectively through large-scale metagenomics-based investigations. The technique used enabled the author to describe diverse and abundant antibiotic resistance genes in nonclinical environments as well as to track their distribution. This was done without leaving the uncultured bacteria behind.

The soil may be a reservoir of larger pools of ARGs than ever imagined and various compartments like farmlands-water interphase, animal farm-surrounding interphase and sites where soil transport may occur due to rain run-off or animal movement may be critical for the occurrence of ARG and may be in focus for the assessment of their occurrence and further spread. Linking the environmental strains with clinic ones, promoted by human activities, might be a vital consideration [52-54]. In these cases, several factors like biofilm formation and quorum sensing (to be discussed later in this article) support the interaction.

\section{RAbs and AMR by Aquatic Microbiota}

Antibiotic concentrations in aquatic environments generally have been found to range from $\mathrm{ng} \cdot \mathrm{L}^{-1}$ to low $\mu \mathrm{g} \cdot \mathrm{L}^{-1}$ levels $[3,4,8]$. In a summary of studies reporting antibiotic concentrations in aquatic environments by Gros et al. [3], the median concentrations in surface and ground water were reported as 0.030 and $0.071 \mu \mathrm{g} \cdot \mathrm{L}^{-1}$ respectively. Table 1 shows some examples of antibiotic concentrations in wastewater and hospital effluents. These concentrations are above the MIC/MBC for all the antibiotics, according to the British Society for Antimicrobial Chemotherapy [55]. The concentrations reduce due to photolytic effects as the RAbs are transported along the path of water flow and guarantees exposure to sub-MIC/sub-lethal concentration [40]. Gullberg et al. [18] demonstrated in vitro that resistant bacteria can be selected for, at antibiotic concentrations lower than the MIC. The half-life varies. For oxytetracycline, for example, it depends on the prevailing conditions in the environment, such as temperature, light intensity and flow rate. For the quinolone oxolinic acid, a mean half-life (photolytic) of 298 days and 509 days in light and dark conditions, respectively, has been reported [56]. The countries listed in Table 1 have low capacities to remove antibiotic contaminants, although improvements have occurred in the conventional WWTPs (e.g., AAO) [57] that are mainly in use.

The concentrations in vitro are different from the ones in the wastewater environment, since the RAbs may form complexes with other chemicals or adsorb onto particulates. The complexes so formed may cause more ecotoxic effects and induce more broad range resilience (resistance) in the bacteria than the original RAbs. Some of these RAbs can further induce the transfer of ARGs and recombinate in aquatic bacteria, at sub-lethal concentrations [58,59], suggesting that exchange of ARGs may be common in environments contaminated with antibiotics.

Assessments of the discharge from the manufacturing companies have shown that extremely high concentrations of antibiotics in wastewater have been closely linked to antibiotic-manufacturing industrial effluents [14]. The concentration decreases with dilution and photolytic effects in the wastewater treatment and in the receiving environment. The original OTC residues of $920 \pm 20 \mathrm{mg} \cdot \mathrm{L}^{-1}$ were reduced to $30.5 \pm 1.1 \mathrm{mg} \cdot \mathrm{L}^{-1}$ when mixed and later to $19.5 \pm 2.9 \mathrm{mg} \cdot \mathrm{L}^{-1}$ in the wastewater effluent. The OTC concentration in the receiving river decreased to $264 \mu \mathrm{g} \cdot \mathrm{L}^{-1}$ (probably by photo-degradation) at $20 \mathrm{~km}$ from the discharge point [47]. This explains the critical impact of industrial effluents (especially from pharmaceutical companies) on the discharge of RAbs and the emergence of resistance. Li et al. [14] further showed that $94.2 \%$ bacterial isolates in wastewater and $95.4 \%$ in receiving water bodies harboured $67.0 \% \operatorname{Tet}(\mathrm{A})$. They also harboured $\operatorname{Tet}(\mathrm{W}), \operatorname{Tet}(\mathrm{C}), \operatorname{Tet}(\mathrm{J})$, Tet(L), Tet(D), Tet(Y), and Tet(K) ranging between $21.0 \%$ and $40.6 \%$. The Tet genes might have been acquired vertically by the microorganisms or emerged by selection as adaptation for survival [60].

Emergence of resistance through bacterial exposure to RAbs in aquatic microbiota depends also on the time of exposure. Li et al. [14] observed that bacterial isolates in downstream parts (after the point of discharge for wastewater effluents) of rivers exhibit higher multiple antibiotic resistance index (MARI) and harbour more ARGs than those upstream of the effluent point. The author ascribed 
this to the impact of wastewater treatment plants as there was a correlation in the observed MAR Index/ARGs between the wastewater and the river studied [14]. Another potential contributing factor is longer exposure time as the bacteria remained exposed to the RAbs present in the water along the path of flow [60]. ARGs residing on plasmids and integrons are also shared when bacteria are together for a longer time [61,62]. More research is hereby advocated for to determine the role of uncultured bacteria in the ARGs surge as reported by Zhang et al. [63]. Meanwhile, pertinent studies have identified ARGs now isolated from treated water as well as among bacteria from freshwater but previously believed to be in exclusive reserve of clinically important bacteria [64-67]. There is further need for studies tracking the source of such genes in aquatic environments accounting for different potential sources of contamination.

\section{Emergence of AMR in Clinical and Sub-Clinical Settings}

The emergence of AMR in clinical settings considers the contribution from human medicine and its impact on hospital-environmental interface, as well as outpatient administration of antibiotics, leading to exposure of individuals to sub-lethal concentrations of antibiotics. Several non-environmental factors have been reported to predicate AMR in clinical settings. However, some factors are underrated, yet they contribute into the alarming rate of AMR emergence in hospitals. The consequence encompasses therapeutic failure, prolonged hospital stay, higher cost of alternative treatment option and possibly higher risk of death [68]. In developing countries where the control on antimicrobial drugs (AMD) administration is weak and antibiotics are sold like over-the-counter (OTC) drugs, individuals with symptoms suspected to be similar to an infectious outcome engage in self-medication prior hospital visit [69]. Self-medication remains a current challenge towards the emergence of AMR [70]. Self-medication is not limited to developing countries. It extends to countries with strict control on drug sales and administration [71]. Figure 1 gives an overview of percentage prevalence of self-medication in developed and middle economic countries. Countries like Switzerland and Italy have lower prevalence of self-medication ( $8 \%$ ) as compared to South Africa (Figure 1), potentially due to sale restrictions. Orally administered AMDs are more subjected to self-medication than parenteral as the former ones are self-administered; in overused and underused regimen, leading to several contraindications, as well as the emergence of AMR [72].

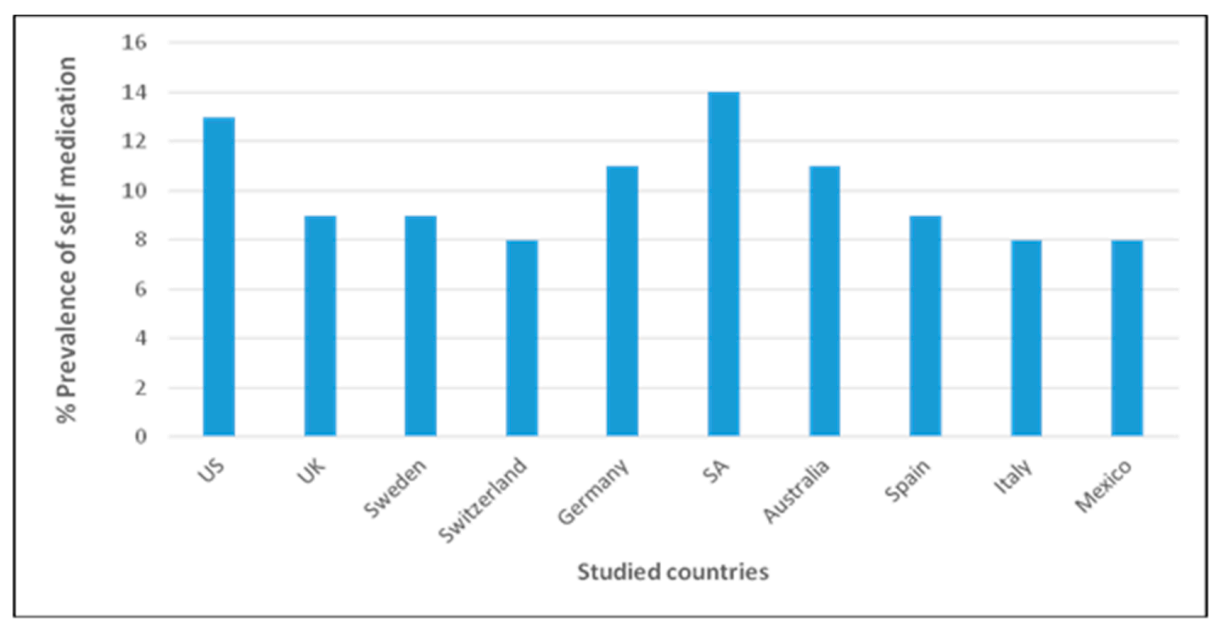

Figure 1. Percentage self-medication in some developed and mid-economic developed countries (Adapted from: http://www.abimip.org.br/uploads/material_de_apoio/1296056417_792.pdf/).

Poor audit system of the prescriptions in many countries has encouraged the prescription of antibiotics without reference to laboratory analysis. Inappropriate prescription is in no way better than self-medication as both promote AMR [72,73]. Between 30\% and 50\% inappropriate prescription reflected by wrong indication, incorrect choices of AMD and regimen have been reported [73,74]. 
These are also closely related to patients' non-compliance to a correct regimen prescribed by physician, the two aberrations lead the failure to achieve and maintain the required plasma concentrations (inhibitory or lethal dose) within the period of drug administration.

Administration of counterfeit drugs also contributes extensively to the emergence of antibiotic resistance in developing countries. Factors contributing to fake or substandard drugs which are common in developing countries include the economic incentives and weak intellectual property protection in those countries. Counterfeit drugs include drugs without active ingredients, drugs with lower concentrations of active ingredients than required and drugs with different ingredients from the indicated label. Drugs with lower concentration of active ingredients are likely to induce antibiotic resistance [75], as bacteria get exposed to sub-lethal concentrations of the drug in vivo and become adapted to them.

\section{Reported Emerging Threat Level of AMR}

As emphasized, emergence of resistance is induced by exposure to RAbs in the soil, wastewater and in hospital environment, contributing to rise in the level of threat to public health. The Centers for Disease Control and Prevention [74] identified the following selected organisms as serious threats especially in the United States: pan-drug resistant (PDR) or extended spectrum drug resistant (XDR) Acinetobacter spp., drug-resistant Campylobacter spp., fluconazole-resistant Candida spp., extended spectrum $\beta$-lactamase-producing Enterobacteriaceae (ESBLs), vancomycin-resistant Enterococci (VRE), multidrug-resistant Pseudomonas aeruginosa, drug-resistant Non-typhoidal Salmonella spp., drug-resistant Salmonella, methicillin-resistant Staphylococcus aureus (MRSA), drug-resistant Streptococcus pneumoniae, total drug-resistant Mycobacterium tuberculosis, etc. The threat associated with these selected microorganisms was described by Senekal [76] as being important in the emerging order of AR. They are therefore further described in Table 2 based on the report of other researchers.

Table 2. Some reported AMR classified as having serious threat.

\begin{tabular}{|c|c|c|c|}
\hline Bacteria Threat Level & $\begin{array}{l}\text { Examples of Reported Antibiotics/Antibiotic Groups } \\
\text { to Which Resistance Occurred }\end{array}$ & $\begin{array}{l}\text { Countries Where This } \\
\text { Has Been Reported }\end{array}$ & References \\
\hline $\begin{array}{l}\text { Pan drug resistant } \\
\text { (PDR)/Extended spectrum } \\
\text { drug resistant (XDR) } \\
\text { Acinetobacter spp. }\end{array}$ & $\begin{array}{l}\text { Resistant to at least } 3 \text { classes + Carbapenems, } \\
\text { polymyxins, tigecycline or fluoroquinolones }\end{array}$ & $\begin{array}{l}\text { Greece, US, India, South Africa, } \\
\text { Iran, Greece }\end{array}$ & [77-82] \\
\hline $\begin{array}{l}\text { Drug resistant } \\
\text { Campylobacter spp. }\end{array}$ & $\begin{array}{l}\text { Range of } 45 \% \text { to } 94.7 \% \text { resistant to Erythromycin, } \\
\text { azithromycin, clindamycin, telithromycin, ciprofloxacin, }\end{array}$ & $\begin{array}{l}\text { US; Finland; Poland; Philippines; } \\
\text { China; Nigeria }\end{array}$ & [83-87] \\
\hline $\begin{array}{l}\text { Extended spectrum } \\
\beta \text {-lactamase producing } \\
\text { Enterobacteriaceae (ESBLs) }\end{array}$ & $\begin{array}{l}23 \% \text { to } 85.1 \% \text { resistant to cephalosporins, gentamicin, } \\
\text { kanamycin, streptomycin, nalidixic acid, ciprofloxacin, } \\
\text { tetracycline, chloramphen-icol, sulfamethoxazole }\end{array}$ & $\begin{array}{l}\text { US, Switzerland, Netherland, Saudi } \\
\text { Arabia, France, Germany, Czech } \\
\text { Republic, Sweden }\end{array}$ & [93-102] \\
\hline $\begin{array}{l}\text { Vancomycin-resistant } \\
\text { Enterococcus (VRE) }\end{array}$ & $\begin{array}{l}\leq 90 \% \text { ampicillin, chloramphen-icol, clindamycin, } \\
\text { ciproflo-xin, erythromycin, neomycin, penicillin, } \\
\text { rifampicin, tetracycline and vancomycin }\end{array}$ & $\begin{array}{l}\text { US, Spain, Portugal Sweden, UK, } \\
\text { Australia, Iran, Ethiopia }\end{array}$ & [103-106] \\
\hline $\begin{array}{l}\text { Drug-resistant Non-typhoidal } \\
\text { Salmonella spp. }\end{array}$ & $\begin{array}{l}\leq 100 \% \text { resistant to nalidixic acid, tetracycline, } \\
\text { streptomycin, ciprofloxacin, azithromycin } \\
\text { and cefotaxime }\end{array}$ & $\begin{array}{l}\text { US, Iran, Egypt, Ethiopia, UK, } \\
\text { China, Congo Republic, Saudi } \\
\text { Arabia, Greece }\end{array}$ & [113-120] \\
\hline Drug-resistant Salmonella & $\begin{array}{l}\text { Resistant to ceftriaxone, cefuroxime, amoxicillin, } \\
\text { ampicillin, ciprofloxacin and augmentin }\end{array}$ & $\begin{array}{l}\text { US, Nigeria, India, Southern Asia } \\
\text { and Kenya }\end{array}$ & [121-125] \\
\hline $\begin{array}{l}\text { Methicillin-resistant } \\
\text { Staphylococcus aureus (MRSA) }\end{array}$ & $\begin{array}{l}\text { Usually resistant to wide range of beta lactam } \\
\text { antibiotics to } \leq 100 \%\end{array}$ & $\begin{array}{l}\text { US, Nigeria, South Africa, Tanzania, } \\
\text { several countries in Europe }\end{array}$ & [126-131] \\
\hline $\begin{array}{l}\text { Drug-resistant } \\
\text { Streptococcus pneumoniae }\end{array}$ & $\begin{array}{l}\text { e.g., } 37 \% \text { were resistant to erythromycin, } 29.6 \% \text { to } \\
\text { cefotaxime, } 7.4 \% \text { to levofloxacin, and } 14.8 \% \text { were } \\
\text { identified as multidrug resistant }\end{array}$ & $\begin{array}{l}\text { US, Spain, India, Austria Belgium, } \\
\text { France, Germany, Italy, Portugal, } \\
\text { Spain and Switzerland }\end{array}$ & [132-138] \\
\hline
\end{tabular}


These organisms are able to effectively develop resistance in clinical settings. In the environment individuals may for example be exposed to them through aerosols from hospital effluents treated in WWTPs. This unfortunately is worsened by the presence of antibiotics in sub-inhibitory concentrations [142]. Chromobacterium violaceum ATCC 12472 was reported by Liu et al. [144] to form antibiotic-induced quorum sensing and biofilm formation which lead to exchange of genetic information and acquisition of resistance in aquatic and terrestrial habitat. Quorum sensing (QS) occurs following the production, detection and cells' response to small diffusible signal molecules called auto-inducers. The molecules determine the type of quorum formed. The possible quorum sensing can be:

a LuxI/LuxR-type quorum sensing: The signal molecules utilized here are the acyl-homoserine lactones (AHL) and they are found in Gram-negative bacteria, for example the complex QS machinery in Acinetobacter is mediated by LuxI/LuxR system peculiar to Gram-negative bacteria. This cell signalling system is made up of AHL [145].

b Oligopeptide-bicomponental quorum sensing: This utilizes small peptides as signal molecules and are found in Gram-positive bacteria.

Therefore, whichever molecule would be produced viz-a-viz the quorum formed depends on the bacterial types as well as the inducing factor (s), but they all affect the biofilm production and the accessibility of the organism to the antibiotics. The procedure for the formation of biofilm is the same in both clinic and the environment.

Meanwhile, the mechanisms associated with biofilm for antibiotic resistance is both innate and induced $[146,147]$. This leads to reduction in the concentration of antibiotics that reach the bacterial cells and their environment [148]. Certain antibiotics like ampicillin penetrate only selected biofilms like those formed by Klebsiella pneumoniae with no potential for $\beta$-lactamase production, but not stable enough to the enzyme to penetrate those formed by wild type with ability to produce the hydrolase [149], so large populations of cells are harboured in biofilms where they undergo genetic exchange leading to antibiotic resistance [150]. Even in human body fluid, bacteria produce biofilms to shield themselves from antibiotics, selective pressure, as well as from opsonin-phagocytosis [151-153]. This is mediated by accessory gene regulator (agr)-mediated quorum sensing in Staphylococci [152]. Beside biofilms, Table 3 further states some other associated attributes and mechanisms that contribute to the emergence of resistance in the bacterial reservoirs.

Table 3. Bacterial attributes besides selection for ARGs that facilitates AMR.

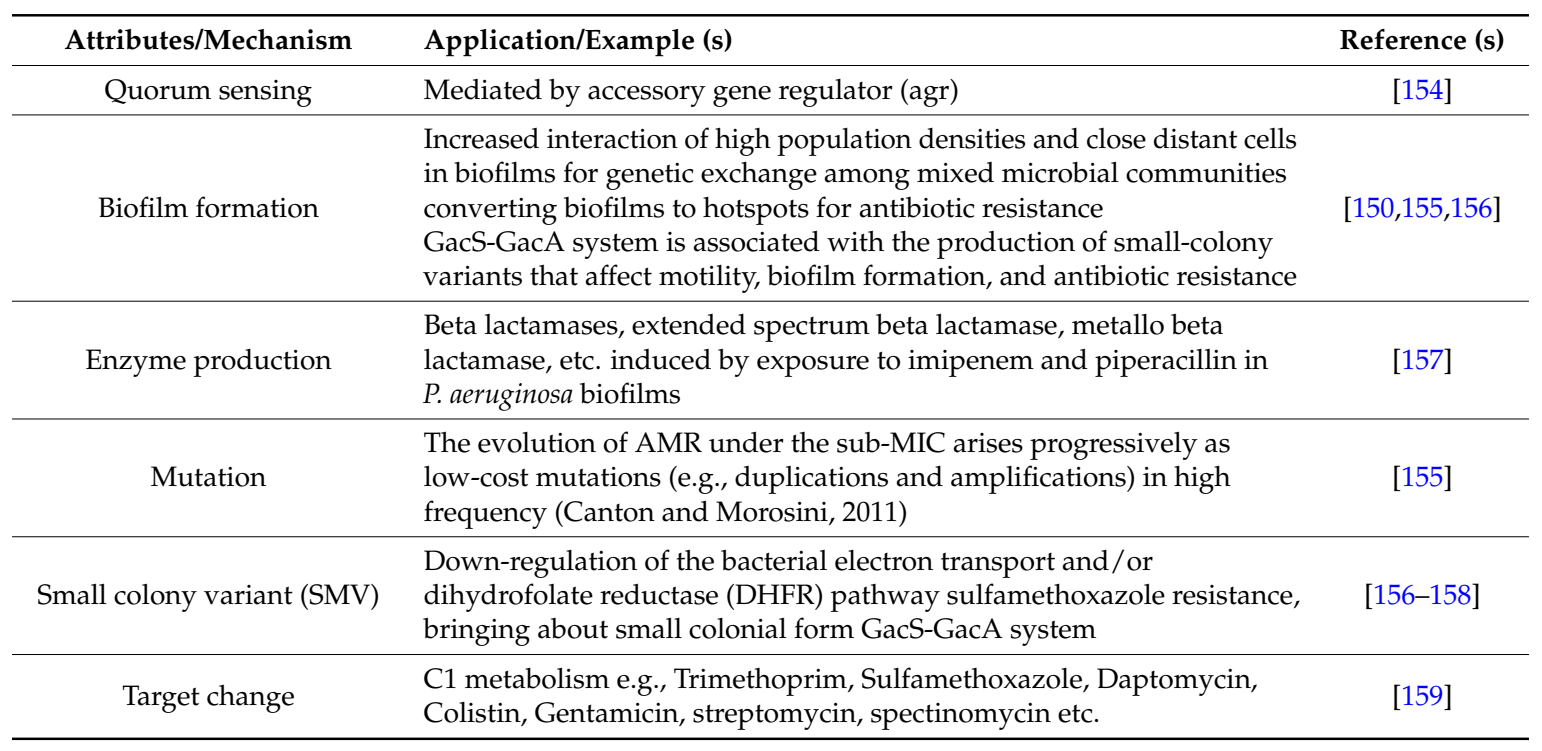


The importance of mutations cannot be overemphasized. Recovery from exposure to sub-inhibitory or sub-lethal concentration of antibiotics may lead to adaptation via mutation. The evolution of AMR under the sub-MIC arises progressively as low-cost mutations (e.g., duplications and amplifications) in high frequencies [155]. This continues in each reservoir where bacteria are exposed to sub-inhibitory concentration of the indicated antibiotics. The trend may be worsened, if the organism(s) is conveyed from one reservoir to another, exposing them to wider range of antibiotics. This is why coordinated efforts in all compartments of the environment are imperative in checkmating the emergence of AMR. Figure 2 clearly depicts the links in various compartment of human environment and how the RAbs, emerging AMR bacteria already getting exposed to RAbs, ARGs, etc. are conveyed in cycles. This long interrelated cycle of exposure and emergence of AMR probably begat the present level of threat and should be addressed at each stage, but in a coordinated manner.

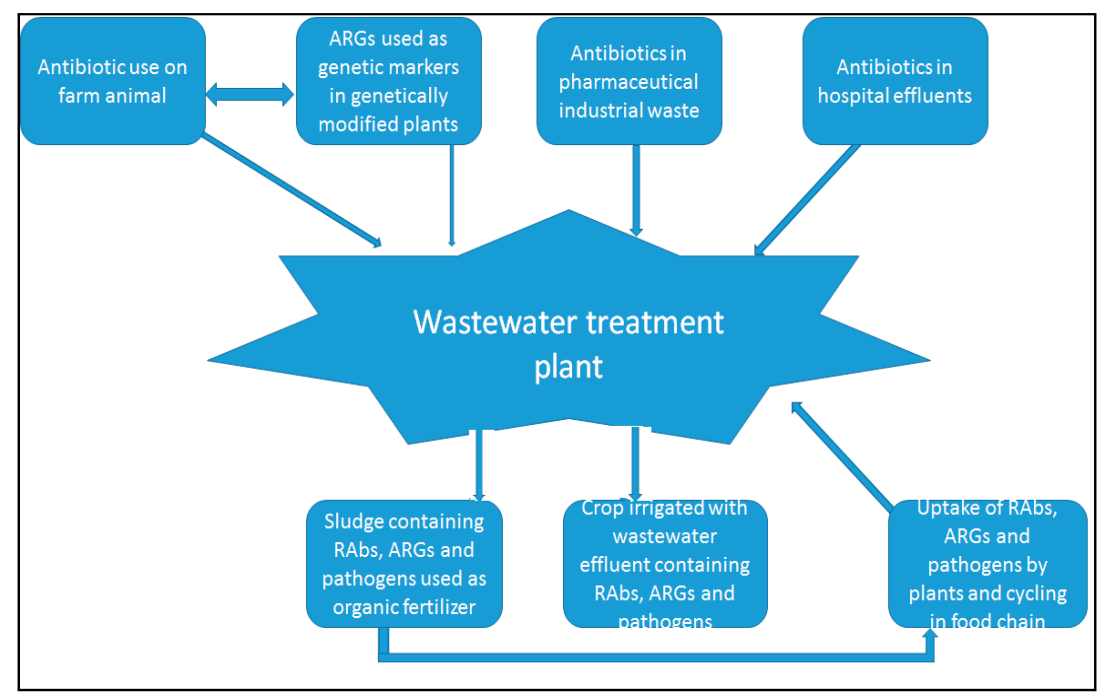

Figure 2. The interrelatedness of contributing factors to AMR (AMR Microbes, RAbs and ARGs are recycled in nature).

\section{Coordinated Approaches towards Addressing the Emergence and Spread of AMR}

Coordinated multi-locational approaches across various segment of the environment should be embraced towards preventing the emergence or spread of AMR and its uprising threat. The global action plan against antimicrobial resistance suggested the outright prevention of any infection or those caused by multiple antibiotic resistant bacteria (MARB) appears as the most likely pathway to follow. This can be achieved directly by personal and general hygiene. There is also an indirect pathway to prevent community (environmentally)-acquired infections by ensuring proper treatment of wastewater. This reduces the associated risks of infection to the user of the effluents and the residents around the receiving water environment. It should be noted that pathogens and RAbs in improperly treated wastewater effluents for reuse in irrigation are reportedly deposited on the surfaces or internalized in fruits and vegetables [33]. Consumption of MARB in uncooked foods like salads poses the greatest risks to the consumers [160,161]. This also applies to the reuse of the improperly treated sludge as organic fertilizer, exposing the farmers and crop consumers to the risks of MARB and difficult-to-treat infections [33]. The spread of MARB through wastewater treatment plants (WWTPs) or sludge deposition to other segments of the environment needs to be controlled and proper treatment applied. The compliance to this is however low, especially in developing economies. It is a settled fact that very low (sub-inhibitory) concentration of antibiotics reaches the river catchments. This may sustain continued development of resistance to antibiotics via exposure. WWTPs have also been identified as potential control points in an early warning system [15,47], especially those 
receiving wastewater from hospitals, which will be hotspot for MARB [1,51]. The two main concerns in integrated human health risk assessment associated with the development and transfer of antibiotic resistance in the environment (i.e., RAbs and ARGs) should therefore be considered in remodelling the WWTPs [162]. Technologies to remove RAbs, ARGs and MARB from wastewater may include membrane filtration, activated carbon, photo-driven nano-technologies and ozonation [163].

It is also imperative to channel more research towards in-depth understanding of the molecular, evolutionary and ecological mechanisms of AMR. Advocatory, legislation and enforcement on the control of drug abuse, restricting the use of antibiotics in agriculture exclusively to therapeutics and enforcing hospitals as well as pharmaceutical companies to own their specially configured WWTPs are pertinent steps. Relatively, the development of more antibiotic regimens in one daily dose (OD) e.g., using gastrointestinal float delivery technology as in Zanocin OD, a brand of ofloxacin [164] will improve patient compliance and reduce the emergence of AMR.

It is the right time to promote more intensive screening for new antimicrobial drug producing bacteria, development of new antibiotics and antibiotic targets as well as developing new diagnostics. Adegoke (unpublished data) discovered a strain of Streptomyces sp. Anthony DS-7A (http://www. uniprot.org/taxonomy/1827503) with far outstanding antimicrobial activity than erythromycin. Similarly, Ling et al. [165] detected a new antibiotic that kills pathogens without detectable resistance. Some of the potential sources of antimicrobial drugs remain unutilized. Palonbo [166] also remarked that despite several reports of high antimicrobial activity against MARB exhibited by plant extracts, very negligible numbers have been promoted to clinical stages. Novel antibiotics targeting the virulent factors and AMR inducing factors like quorum quenching to interfere with quorum sensing and biofilm formation have been solicited $[167,168]$. Such potent antibiotics should be able to hack into the bacterial biofilm [169], break its edges and ensure penetration of inhibitory concentration of its active ingredients to attack shielded bacteria.

\section{Conclusions}

Coordinated approaches to reduce integrated human health risks in the environment as well as careful compliance with the WHO guidelines [170] on surveillance, rational antibiotic prescribing, standard treatment guidelines for both community- and hospital-acquired infections will lead appreciably towards reducing the ever-rising threat of antibiotic resistance. Strategic steps related to assessment and management in various environmental reservoirs and niches will assert collective reduction in the threat and prevent the emergence of more aggressive superbugs.

Acknowledgments: We acknowledge the SARChI, Durban University of Technology of the National Research Foundation (NRF) for support.

Conflicts of Interest: The authors declare no conflict of interest.

\section{References}

1. Rizzo, L.; Manaia, C.; Merlin, C.; Schwartz, T.; Dagot, C.; Ploy, M.C.; Michael, I.; Fatta-Kassinos, D. Urban wastewater treatment plants as hotspots for antibiotic resistant bacteria and genes spread into the environment: A review. Sci. Total Environ. 2013, 447, 345-360. [CrossRef] [PubMed]

2. Bérdy, J. Bioactive microbial metabolites. J. Antibiot. 2005, 58, 1-26. [CrossRef] [PubMed]

3. Gros, M.; Petrović, M.; Barceló, D. Multi-residue analytical methods using LC-tandem MS for the determination of pharmaceuticals in environmental and wastewater samples: A review. Anal. Bioanal. Chem. 2006, 386, 941-952. [CrossRef] [PubMed]

4. Segura, P.A.; François, M.; Gagnon, C.; Sauvé, S. Review of the occurrence of anti-infectives in contaminated wastewaters and natural drinking waters. Environ. Health Perspect. 2009, 117, 675-684. [CrossRef] [PubMed]

5. Allen, H.K.; Donato, J.; Wang, H.H.; Cloud-Hansen, K.A.; Davies, J.; Handelsman, J. Call of the wild: Antibiotic resistance genes in natural environments. Nat. Rev. Microbiol. 2010, 8, 251-259. [CrossRef] [PubMed] 
6. D'Costa, V.M.; King, C.E.; Kalan, L.; Morar, M.; Sung, W.W.L.; Schwarz, C.; Froese, D.; Zazula, G.; Calmels, F.; Debruyne, R.; et al. Antibiotic resistance is ancient. Nature 2011, 477, 457-461. [CrossRef] [PubMed]

7. Forsberg, K.J.; Reyes, A.; Wang, B.; Selleck, E.M.; Sommer, M.O.A.; Dantas, G. The shared antibiotic resistome of soil bacteria and human pathogens. Science 2012, 337, 1107-1111. [CrossRef] [PubMed]

8. Hughes, S.R.; Kay, P.; Brown, L.E. Global synthesis and critical evaluation of pharmaceutical data sets collected from river systems. Environ. Sci. Technol. 2013, 47, 661-677. [CrossRef] [PubMed]

9. Gillings, M.R. Evolutionary consequences of antibiotic use for the resistome, mobilome and microbial pangenome. Front. Microbiol. 2013, 4. [CrossRef] [PubMed]

10. Baquero, F.; Martínez, J.L.; Cantón, R. Antibiotics and antibiotic resistance in water environments. Curr. Opin. Biotechnol. 2008, 19, 260-265. [CrossRef] [PubMed]

11. Pei, R.; Kim, S.C.; Carlson, K.H.; Pruden, A. Effect of river landscape on the sediment concentrations of antibiotics and corresponding antibiotic resistance genes (ARG). Water Res. 2006, 40, 2427-2435. [CrossRef] [PubMed]

12. Pruden, A.; Arabi, M.; Storteboom, H.N. Correlation between upstream human activities and riverine antibiotic resistance genes. Environ. Sci. Technol. 2012, 46, 11541-11549. [CrossRef] [PubMed]

13. Khan, G.A.; Berglund, B.; Khan, M.K.; Lindgren, P.E.; Fick, J. Occurrence and abundance of antibiotics and resistance genes in rivers, canal and near drug formulation facilities-A study in Pakistan. PLoS ONE 2013, 8, e62712. [CrossRef] [PubMed]

14. Li, D.; Yu, T.; Zhang, Y.; Yang, M.; Li, Z.; Liu, M.; Qi, R. Antibiotic resistance characteristics of environmental bacteria from an oxytetracycline production wastewater treatment plant and the receiving river. Appl. Environ. Microbiol. 2010, 76, 3444-3451. [CrossRef] [PubMed]

15. Kristiansson, E.; Fick, J.; Janzon, A.; Grabic, R.; Rutgersson, C.; Weijdegård, B.; Söderström, H.; Joakim Larsson, D.G. Pyrosequencing of antibiotic-contaminated river sediments reveals high levels of resistance and gene transfer elements. PLoS ONE 2011, 6, e17038. [CrossRef] [PubMed]

16. Holmberg, S.D.; Solomon, S.L.; Blake, P.A. Health and economic impacts of antimicrobial resistance. Rev. Infect. Dis. 1987, 9, 1065-1078. [CrossRef] [PubMed]

17. Cheng, G.; Hu, Y.; Yin, Y.; Yang, X.; Xiang, C.; Wang, B.; Chen, Y.; Yang, F.; Lei, F.; Wu, N.; et al. Functional screening of antibiotic resistance genes from human gut microbiota reveals a novel gene fusion. FEMS Microbiol. Lett. 2012, 336, 11-16. [CrossRef] [PubMed]

18. Gullberg, E.; Cao, S.; Berg, O.G.; Ilbäck, C.; Sandegren, L.; Hughes, D.; Andersson, D.I. Selection of resistant bacteria at very low antibiotic concentrations. PLoS Pathog. 2011, 7, e1002158. [CrossRef] [PubMed]

19. World Health Organization. Global Action Plan on Antimicrobial Resistance; World Health Organization: Geneva, Switzerland, 2015.

20. Serrano, P.H. Responsible Use of Antibiotics in Aquaculture; In FAO Fisheries Technical Paper 469 (Rome; United Nations); Food and Agriculture Organization of the United Nations: Rome, Italy, 2005; p. 89.

21. Smith, P.R.; LeBreton, A.; Horsberg, T.E.; Corsin, F. Guidelines for antimicrobial use in aquaculture. In Guide to Antimicrobial Use in Animals; Guardabassi, L., Jensen, L.B., Kruse, H., Eds.; Blackwell Publishing Ltd.: Oxford, UK, 2009; pp. 207-218.

22. Waksman, S.A. Antagonistic relations of microorganisms. Bacteriol. Rev. 1941, 5, 231-291. [PubMed]

23. Lewis, I.M. Bacterial antagonism with special reference to the effect of Pseudomonas fluorescens on spore forming bacteria of soils. J. Bacteriol. 1929, 17, 89-103. [PubMed]

24. Waksman, S.A.; Woodruff, H.B. The soil as a source of microorganisms antagonistic to disease producing bacteria. J. Bacteriol. 1940, 40, 581-600. [PubMed]

25. Florey, H.W. The use of micro-organisms for therapeutic purposes. Yale J. Biol. Med. 1946, 19, $101-117$. [CrossRef] [PubMed]

26. Smith, T. Antibiotics from soil bacteria. Nat. Struct. Biol. 2000, 7, 189-190. [CrossRef] [PubMed]

27. Plough, H.H. Penicillin resistance of Staphylococcus aureus and its clinical implications. Am. J. Clin. Pathol. 1945, 15, 446-451. [CrossRef] [PubMed]

28. Cox, G.; Wright, G.D. Intrinsic antibiotic resistance: mechanisms, origins, challenges and solutions. Int. J. Med. Microbiol. 2013, 303, 287-292. [CrossRef] [PubMed]

29. Benveniste, R.; Davies, J. Aminoglycoside antibiotic-inactivating enzymes in actinomycetes similar to those present in clinical isolates of antibiotic-resistant bacteria. Proc. Natl. Acad. Sci. USA 1973, 70, 2276-2280. [CrossRef] [PubMed] 
30. Nesme, J.; Cécillon, S.; Delmont, T.O.; Monier, J.-M.; Vogel, T.M.; Simonet, P. Large-scale metagenomics based study of antibiotic resistance in the environment. Curr. Biol. 2014, 10, 1096-1100. [CrossRef] [PubMed]

31. Rosenberg, G.; Steinberg, N.; Oppenheimer-Shaanan, N.; Olender, T.; Doron, S.; Ben-Ari, J.; Sirota-Madi, A.; Bloom-Ackermann, Z.; Kolodkin-Gal, I. Not so simple, not so subtle: The interspecies competition between Bacillus simplex and Bacillus subtilis and its impact on the evolution of biofilms. NPJ Biofilms Microbiomes 2016, 2, 15027. [CrossRef]

32. Vas-Moreira, I.; Nune, O.C.; Manaia, C.M. Bacterial diversity and antibiotic resistance in water habitats: searching the links with the human microbiome. FEM Microbiol. Rev. 2014, 38, 718-761. [CrossRef] [PubMed]

33. Adegoke, A.A.; Awolusi, O.O.; Stenström, T.A. Organic Fertilizers: Public Health Intricacies. In Organic Fertilizers_From Basic Concepts to Applied Outcomes; Larramendy, M., Ed.; INTECH: Vienna, Austria, 2016.

34. McEwen, S.A.; Fedorka-Cray, P.J. Antimicrobial use and resistance in animals. Clin. Infect. Dis. 2002, 34 (Suppl. S3), S93-S106. [CrossRef] [PubMed]

35. Butaye, P.; Devriese, L.A.; Haesebrouck, F. Antimicrobial growth promoters used in animal feed: Effects of less well known antibiotics on gram-positive bacteria. Clin. Microbiol. Rev. 2003, 16, 175-188. [CrossRef] [PubMed]

36. APUA's International Surveillance of Reservoirs of Resistance (ISRAR) 2008-2010. Available online: http:/ / emerald.tufts.edu/med/apua/research/israr_10_957998750.pdf (accessed on 11 October 2016).

37. Wang, M.; Tang, J.C. Research of antibiotics pollution in soil environments and its ecological toxicity. J. Agro-Environ. Sci. 2010, 29, 261-266.

38. McManus, P.S.; Stockwell, V.O.; Sundin, G.W.; Jones, A.L. Antibiotic use in plant agriculture. Ann. Rev. Phytopathol. 2002, 40, 443-465. [CrossRef] [PubMed]

39. Pan, X.; Qiang, Z.M.; Ben, W.W.; Chen, M.X. Residual veterinary antibiotics in swine manure from concentrated animal feeding operations in Shandong Province, China. Chemosphere 2011, 84, 695-700. [CrossRef] [PubMed]

40. Cheng, V.C.C.; Wong, S.C.Y.; Ho, P.L.; Yuen, K.Y. Strategic measures for the control of surging antimicrobial resistance in Hong Kong and mainland of China. Emerg. Microbes Infect. 2015, 4, e8. [CrossRef] [PubMed]

41. Pace, N.R. Mapping the tree of life: Progress and prospects. Microbiol. Mol. Biol. Rev. 2009, 73, 565-576. [CrossRef] [PubMed]

42. Hussain, M.; Zouhar, M.; Ryšánek, P.; Anwar, S.A. Relationship between meloidogyne incognita density and plant growth of okra. J. Anim. Plant Sci. 2016, 26, 739-744.

43. Zhang, H.; Luo, Y.; Wu, L.; Huang, Y.; Christie, P. Residues and potential ecological risks of veterinary antibiotics in manures and composts associated with protected vegetable farming. Environ. Sci. Pollut. Res. Int. 2015, 22, 5908-5918. [CrossRef] [PubMed]

44. Zhang, H.; Zhou, Y.; Huang, Y.; Wu, L.; Liu, X.; Luo, Y. Residues and risks of veterinary antibiotics in protected vegetable soils following application of different manures. Chemosphere 2016, 152, 229-237. [CrossRef] [PubMed]

45. Furtula, V.; Farrell, E.G.; Diarrassouba, F.; Rempel, H.; Pritchard, J.; Diarra, M.S. Veterinary pharmaceuticals and antibiotic resistance of Escherichia coli isolates in poultry litter from commercial farms and controlled feeding trials. Poultry Sci. 2010, 89, 180-188. [CrossRef] [PubMed]

46. Watkinson, A.J.; Murby, E.J.; Kolpin, D.W.; Costanzo, S.D. The occurrence of antibiotics in an urban watershed: from wastewater to drinking water. Sci. Total Environ. 2009, 407, 2711-2723. [CrossRef] [PubMed]

47. Li, D.; Yang, M.; Hu, J.; Zhang, J.; Liu, R.; Gu, X.; Zhang, Y.; Wang, Z. Antibiotic-resistance profile in environmental bacteria isolated from penicillin production wastewater treatment plant and the receiving river. Environ. Microbiol. 2009, 11, 1506-1517. [CrossRef] [PubMed]

48. Zuccato, E.; Castiglioni, S.; Fanelli, R. Identification of the pharmaceuticals for human use contaminating the Italian aquatic environment. J. Hazard. Mater. 2005, 122, 205-209. [CrossRef] [PubMed]

49. Ternes, T.A.; Hirsch, R. Occurrence and behavior of X-ray contrast media in sewage facilities and the aquatic environment. Environ. Sci. Technol. 2000, 34, 2741-2748. [CrossRef]

50. Castiglioni, S.; Fanelli, R.; Calamari, D.; Bagnati, R.; Zuccato, E. Methodological approaches for studying pharmaceuticals in the environment by comparing predicted and measured concentrations in River Po, Italy. Regul. Toxicol. Pharmacol. 2004, 39, 25-32. [CrossRef] [PubMed] 
51. Berto, J.; Rochenbach, G.C.; Barreiros, M.A.B.; Correa, A.X.R.; Peluso-Silva, S.; Radetski, C.M. Physicochemical, microbiological, and ecotoxicological evaluation of a septic tank/Fenton reaction combination for the treatment of hospital wastewaters. Ecotoxicol. Environ. Saf. 2009, 72, 1076-1081. [CrossRef] [PubMed]

52. Heuer, H.; Smalla, K. Plasmids foster diversification and adaptation of bacterial populations in soil. FEMS Microbiol. Rev. 2012, 36, 1083-1104. [CrossRef] [PubMed]

53. Gaze, W.H.; Zhang, L.; Abdouslam, N.A.; Hawkey, P.M.; Calvo-Bado, L.; Royle, J.; Brown, H.; Davis, S.; Kay, P.; Boxall, A.B.; et al. Impacts of anthropogenic activity on the ecology of class 1 integrons and integron-associated genes in the environment. ISME J. 2011, 5, 1253-1261. [CrossRef] [PubMed]

54. Nardelli, M.; Scalzo, P.M.; Ramírez, M.S.; Quiroga, M.P.; Cassini, M.H.; Centrón, D. Class 1 integrons in environments with different degrees of urbanization. PLoS ONE 2012, 7, e39223. [CrossRef] [PubMed]

55. British Society for Antimicrobial Chemotherapy. Standing Committee on Susceptibility Testing; Version 14.0; British Society for Antimicrobial Chemotherapy: Birmingham, UK, 2015.

56. Lai, H.T.; Chien, Y.H.; Lin, J.S. Long-term transformation of oxolinic acid in water from an eel pond. Aquaculture 2008, 275, 96-101. [CrossRef]

57. Zhang, Q.H.; Yang, W.N.; Ngo, H.H.; Guo, W.S.; Jin, P.K.; Dzakpasu, M.; Yang, S.J.; Wang, Q.; Wang, X.C.; Ao, D. Current status of urban wastewater treatment plants in China. Environ. Int. 2016, 92-93, 11-22. [CrossRef] [PubMed]

58. Beaber, J.W.; Hochhut, B.; Waldor, M.K. SOS response promotes horizontal dissemination of antibiotic resistance genes. Nature 2004, 427, 72-74. [CrossRef] [PubMed]

59. Ubeda, C.; Maiques, E.; Knecht, E.; Lasa, I.; Novick, R.P.; Penadés, J.R. Antibiotic-induced SOS response promotes horizontal dissemination of pathogenicity island-encoded virulence factors in Staphylococci. Mol. Microbiol. 2005, 56, 836-844. [CrossRef] [PubMed]

60. Davies, J.; Davies, D. Origins and Evolution of Antibiotic Resistance. Microbiol. Mol. Biol. Rev. 2010, 74, 417-433. [CrossRef] [PubMed]

61. Garcilla'n-Barcia, M.P.; Alvarado, A.; de la Cruz, F. Identification of bacterial plasmids based on mobility and plasmid population biology. FEMS Microbiol. Rev. 2011, 35, 936-956. [CrossRef] [PubMed]

62. Partridge, S.R. Analysis of antibiotic resistance regions in Gram-negative bacteria. FEMS Microbiol. Rev. 2011, 35, 820-855. [CrossRef] [PubMed]

63. Zhang, T.; Zhang, X.X.; Ye, L. Plasmid metagenome reveals high levels of antibiotic resistance genes and mobile genetic elements inactivated sludge. PLoS ONE 2011, 6, e26041. [CrossRef] [PubMed]

64. Farias, T.; de Menorval, L.C.; Zajac, J.; Rivera, A. Benzalkonium chloride and sulfamethoxazole adsorption onto natural clinoptilolite: Effect of time, ionic strength, $\mathrm{pH}$ and temperature. J. Colloid Interface Sci. 2011, 363, 465-475. [CrossRef] [PubMed]

65. Xi, C.; Zhang, Y.; Marrs, C.F.; Wen, Y.; Carl, S.; Betsy, F.; Jerome, N. Prevalence of antibiotic resistance in drinking water treatment and distribution systems. Appl. Environ. Microbiol. 2009, 75, 5714-5718. [CrossRef] [PubMed]

66. Figueira, V.; Vaz-Moreira, I.; Silva, M.; Manaia, C.M. Diversity and antibiotic resistance of Aeromonas spp. In drinking and waste water treatment plants. Water Res. 2011, 45, 5599-5611. [CrossRef] [PubMed]

67. Stenström, T.A.; Okoh, A.I.; Adegoke, A.A. Antibiogram of environmental isolates of Acinetobacter calcoaceticus from Nkonkobe Municipality, South Africa. Fresenius Environ. Bull. 2016, 25, 3059-3065.

68. Brusselaers, N.; Vogelaers, D.; Blot, S. The rising problem of antimicrobial resistance in the intensive care unit. Ann. Intensive Care 2011, 1, 47. [CrossRef] [PubMed]

69. Vizhi, S.K.; Senapathi, R. Evaluation of the perception, attitude and practice of self-medication among business students in 3 select Cities, South India. Int. J. Enterp. Innov. Manag. Stud. 2010, 1, 40-44.

70. Bennadi, D. Self-medication: A current challenge. J. Basic Clin. Pharm. 2014, 5, 19-23. [CrossRef] [PubMed]

71. Pagán, J.A.; Ross, S.; Yau, J.; Polsky, D. Self-medication and health insurance coverage in Mexico. Health Policy 2006, 75, 170-177. [CrossRef] [PubMed]

72. Pan, H.; Cui, B.; Zhang, D.; Farrar, J.; Law, F.; Ba-Thein, W. Prior knowledge, older age, and higher allowance are risk factors for self-medication with antibiotics among university students in southern China. PLoS ONE 2012, 7, e41314. [CrossRef] [PubMed]

73. Luyt, C.E.; Bréchot, N.; Trouillet, J.L.; Chastre, J. Antibiotic stewardship in the intensive care unit. Crit. Care 2014, 18, 480. [CrossRef] [PubMed] 
74. Centers for Disease Control and Prevention, Office of Infectious Disease Antibiotic Resistance Threats in the United States, 2013. Available online: http://www.cdc.gov/drugresistance/threat-report-2013 (accessed on 28 June 2016).

75. Ventola, L. The Antibiotic Resistance Crisis. Pharm. Ther. 2015, 40, 277-284.

76. Senekal, M. Current resistance issues in antimicrobial therapy. CME 2010, 28, 54-57.

77. Perez, F.; Hujer, A.M.; Hujer, K.M.; Decker, B.K.; Rather, P.N.; Bonomo, R.A. Global challenge of multidrug-resistant Acinetobacter baumannii. Antimicrob. Agents Chemother. 2007, 51, 3471-3484. [CrossRef] [PubMed]

78. Falagas, M.E.; Karageorgopoulos, D.E. Pandrug Resistance (PDR), Extensive Drug Resistance (XDR), and Multidrug Resistance (MDR) among Gram-Negative Bacilli: Need for International Harmonization in Terminology. Clin. Infect. Dis. 2008, 46, 1121-1122. [CrossRef] [PubMed]

79. Adegoke, A.A.; Mvuyo, T.; Okoh, A.I. Ubiquitous Acinetobacter species as beneficial commensals but gradually being emboldened with antibiotic resistance genes. J. Basic Microbiol. 2012, 52, 1-8. [CrossRef] [PubMed]

80. Shakibaie, M.R.; Adeli, S.; Salehi, M.H. Antibiotic resistance patterns and extended spectrum beta-lactamase production among Acinetobacter spp. isolated from anintensive care Unit of a hospital in Kerman, Iran. Antimicrob. Resist. Infect. Control 2012, 1, 1. [CrossRef] [PubMed]

81. Sivaranjani, V.; Umadevi, S.; Srirangaraj, S.; Kali, A.; Seetha, K.S. Multi-drug resistant Acinetobacter species from various clinical samples in a tertiary care hospital from South India. AMJ 2013, 6, 697-700. [CrossRef] [PubMed]

82. Souli, M.; Galani, I.; Giamarellou, H. Emergence of extensively drug-Resistant and pandrug-Resistant Gram-Negative bacilli in Europe. Eurosurveillance 2008, 13, 1-11.

83. Luangtongkum, T.; Jeon, B.; Han, J.; Plummer, P.; Logue, C.M.; Zhang, Q. Antibiotic resistance in Campylobacter: Emergence, transmission and persistence. Future Microbiol. 2009, 4, 189-200. [CrossRef] [PubMed]

84. Lehtopolku, M.; Nakari, U.-M.; Kotilainen, P.; Huovinen, P.; Siitonen, A.; Hakanen, A.J. Antimicrobial Susceptibilities of Multidrug-Resistant Campylobacter jejuni and, C. coli Strains: In Vitro Activities of 20 Antimicrobial Agents. Antimicrob. Agents Chemother. 2010, 54, 1232-1236. [CrossRef] [PubMed]

85. Wieczorek, K.; Osek, J. Antimicrobial Resistance Mechanisms among Campylobacter. BioMed Res. Int. 2013, 2013, 340605. [CrossRef] [PubMed]

86. Sison, F.B.; Chaisowwong, W.; Alter, T.; Tiwananthagorn, S.; Pichpol, D.; Lampang, K.N.; Baumann, M.P.O.; Gölz, G. Loads and antimicrobial resistance. Poult. Sci. 2014, 93, 1270-1273. [CrossRef] [PubMed]

87. Ngulukun, S.S.; Oboegbulem, S.S.; Fagbamila, I.; Barde, I. Antimicrobial resistance of Campylobacter jejuni and Campylobacter coli isolated from chickens in a diagnostic laboratory. Afr. J. Microbiol. Res. 2005, 9, 2197-2201.

88. Garnacho-Montero, J.; Díaz-Martín, A.; García-Cabrera, P.; de Pipao, M.R.; Hernández-Caballero, C. Risk Factors for Fluconazole-Resistant Candidemia. Antimicrob. Agent Chemother. 2010, 54, 3149-3154. [CrossRef] [PubMed]

89. Spampinato, C.; Leonardi, D. Candida Infections, Causes, Targets, and Resistance Mechanisms: Traditional and Alternative Antifungal Agents. BioMed Res. Int. 2013, 2013, 204237. [CrossRef] [PubMed]

90. Centers for Disease Control and Prevention. Antifungal Resistance. August 2016. Available online: http:/ / www.cdc.gov/fungal/antifungal-resistance.html (accessed on 9 September 2016).

91. Liao, X.; Qiu, H.; Li, R.; Guo, F.; Liu, W.; Kang, M.; Kang, Y. Risk factors for fluconazole-resistant invasive candidiasis in intensive care unit patients: An analysis from the China Survey of Candidiasis study. J. Crit. Care 2015, 30, 862.e1-862.e5. [CrossRef] [PubMed]

92. Owotade, F.J.; Gulube, Z.; Ramla, S.; Patel, M. Antifungal susceptibility of Candida albicans isolated from the oral cavities of patients with HIV infection and cancer. SADJ 2016, 71, 8-11.

93. Kolar, M.; Bardon, J.; Chroma, M.; Hricova, K.; Stosova, T.; Sauer, P.; Koukalova, D. ESBL and AmpC beta-lactamase-producing Enterobacteriaceae in poultry in the Czech Republic. Vet. Med. 2010, 55, 119-124.

94. Tärnberg, M. Extended-Spectrum Beta-Lactamase Producing Enterobacteriaceae; Linköping University Medical Dissertations; Linköping University: Linköping, Sweden, 2012.

95. Zurfluh, K.; Hächler, H.; Nüesch-Inderbinen, M.; Stephan, R. Characteristics of Extended-Spectrum $\beta$-Lactamase-and Carbapenemase-Producing Enterobacteriaceae Isolates from Rivers and Lakes in Switzerland. Appl. Environ. Microbiol. 2013, 79, 3021-3026. [CrossRef] [PubMed] 
96. Kandeel, A. Prevalence and risk factors of extended-spectrum $\beta$-lactamases producing Enterobacteriaceae in a general hospital in Saudi Arabia. J. Microbiol. Infect. Dis. 2014, 4, 50-54. [CrossRef]

97. Schmiedel, J.; Falgenhauer, L.; Domann, E.; Bauerfeind, R.; Prenger-Berninghoff, E.; Imirzalioglu, C.; Chakraborty, T. Multiresistant extended-spectrum $\beta$-lactamase-producing Enterobacteriaceae from humans, companion animals and horses in central Hesse, Germany. BMC Microbiol. 2014, 14, 187. [CrossRef] [PubMed]

98. Pilmis, B.; Delory, T.; Groh, M.; Weiss, E.; Emirian, A.; Lecuyer, H.; Lesprit, P.; Zahar, J.-R. Extended-spectrum beta-lactamase-producing Enterobacteriaceae (ESBL-PE) infections: Are carbapenem alternatives achievable in daily practice? Int. J. Infect. Dis. 2015, 39, 62-67. [CrossRef] [PubMed]

99. Lukac, P.J.; Bonomo, R.A.; Logan, L.K. Extended-Spectrum $\beta$-Lactamase-Producing Enterobacteriaceae in Children: Old Foe, Emerging Threat. Clin. Infect. Dis. 2015, 60, 1389-1397. [CrossRef] [PubMed]

100. Willemsen, I.; Oome, S.; Verhulst, C.; Pettersson, A.; Verduin, K.; Kluytmans, J. Trends in Extended Spectrum Beta-Lactamase (ESBL) Producing Enterobacteriaceae and ESBL Genes in a Dutch Teaching Hospital, Measured in 5 Yearly Point Prevalence Surveys (2010-2014). PLoS ONE 2015, 10, e0141765. [CrossRef] [PubMed]

101. Sahlström, L.; Rehbinder, V.; Albihn, A.; Aspan, A.; Bengtsson, B. Vancomycin resistant enterococci (VRE) in Swedish sewage sludge. Acta Vet. Scand. 2009, 51, 24. [CrossRef] [PubMed]

102. Molton, J.S.; Tambyah, P.A.; Ang, B.S.P.; Ling, M.L.; Fisher, D.A. The Global Spread of Healthcare-Associated Multidrug-Resistant Bacteria: A Perspective from Asia. Clin. Infect. Dis. 2013, 56, 1310-1318. [PubMed]

103. Varela, A.R.; Ferro, G.; Vredenburg, J.; Yanik, M.; Vieira, L.; Rizzo, L.; Lameiras, C.; Manaia, C.M. Vancomycin resistant enterococci: From the hospital effluent to the urban wastewater treatment plant. Sci. Total Environ. 2013, 450-451, 155-161. [CrossRef] [PubMed]

104. Abebe, W.; Endris, M.; Tiruneh, M.; Moges, F. Prevalence of vancomycin resistant Enterococci and associated risk factors among clients with and without HIV in Northwest Ethiopia: A cross-sectional study. BMC Public Health 2014, 14, 185. [CrossRef] [PubMed]

105. Goldstein, R.E.R.; Micallef, S.A.; Gibbs, S.G.; George, A.; Claye, E.; Sapkota, E.; Josepha, S.W.; Sapkota, A.R. Detection of vancomycin-resistant enterococci (VRE) at four, U.S. wastewater treatment plants that provide effluent for reuse. Sci. Total Environ. 2014, 466-467, 404-411. [CrossRef] [PubMed]

106. Daniel, D.S.; Lee, S.M.; Dykes, G.A.; Rahman, S. Public Health Risks of Multiple-Drug-Resistant Enterococcus spp. in Southeast Asia. Appl. Environ. Microbiol. 2015, 81, 6090-6097. [CrossRef] [PubMed]

107. Lister, P.D.; Wolter, D.J.; Hanson, N.D. Antibacterial-Resistant Pseudomonas aeruginosa: Clinical Impact and Complex Regulation of Chromosomally Encoded Resistance Mechanisms. Clin. Microbiol. Rev. 2009, 22, 582-610. [CrossRef] [PubMed]

108. Hirsch, E.B.; Tam, V.H. Impact of multidrug-resistant Pseudomonas aeruginosa infection on patient outcomes. Expert Rev. Pharmacoecon. Outcomes Res. 2010, 10, 441-451. [CrossRef] [PubMed]

109. Akingbade, O.A.; Balogun, S.A.; Ojo, D.A.; Afolabi, R.O.; Motayo, B.O.; Okerentugba, P.O.; Okonko, I.O. Plasmid Profile Analysis of Multidrug Resistant Pseudomonas aeruginosa isolated from Wound Infections in South West, Nigeria. World Appl. Sci. J. 2012, 20, 766-775.

110. Meletis, G.; Bagkeri, M. Pseudomonas aeruginosa: Multi-Drug-Resistance Development and Treatment Options; INTECH: Vienna, Austria, 2013.

111. Rizvi, M.; Ahmad, J.; Khan, F.; Shukla, I.; Malik, A.; Sami, H. Synergy of drug combinations in treating multidrug-resistant Pseudomonas aeruginosa. Australas. Med. J. 2015, 8, 1-6. [CrossRef] [PubMed]

112. Yayan, J.; Ghebremedhin, B.; Rasche, K. Antibiotic Resistance of Pseudomonas aeruginosa in Pneumonia at a Single University Hospital Center in Germany over a 10-Year Period. PLoS ONE 2015, 10, e0139836. [CrossRef] [PubMed]

113. Mijovic, G.; Andric, B.; Terzic, D.; Lopicic, M.; Dupanovic, B. Antibiotic susceptibility of salmonella spp.: A comparison of two surveys with a 5 years interval. J. IMAB Annu. Proc. 2012, 18. [CrossRef]

114. Fallah, S.H.; Asgharpour, F.; Naderian, Z.; Moulana, Z. Isolation and Determination of Antibiotic Resistance Patterns in Non-typhoid Salmonella spp. isolated from chicken. Int. J. Enteric Pathog. 2013, 1, 17-21. [CrossRef]

115. Al Ayed, M.S.Z. Prevalence of nontyphoidal Salmonella serotypes and the antimicrobial resistance in pediatric patients in Najran Region, Saudi Arabia. Int. J. Curr. Microbiol. App. Sci. 2014, 3, 103-107.

116. Khairy, R.M.M. Anti-Microbial Resistance of Non-Typhoid Salmonella in Egypt. Ferment. Technol. 2015, 4, 123. 
117. Eguale, T.; Gebreyes, W.A.; Asrat, D.; Alemayehu, H.; Gunn, J.S.; Engidawork, E. Non-typhoidal Salmonella serotypes, antimicrobial resistance and co-infection with parasites among patients with diarrhea and other gastrointestinal complaints in Addis Ababa, Ethiopia. BMC Infect. Dis 2015, 15, 497. [CrossRef] [PubMed]

118. Hsu, C.Y.; Hsu, B.M.; Ji, B.M.; Chen, J.S.; Hsu, T.K.; Ji, D.D.; Tseng, S.F.; Chiu, Y.S.; Kao, P.M.; Huang, Y.L. Antibiotic resistance pattern and gene expression of non-typhoid Salmonella in riversheds. Environ. Sci. Pollut. Res. 2015, 22, 7843-7850. [CrossRef] [PubMed]

119. Liang, Z.; Ke, B.; Deng, X.; Liang, J.; Ran, L.; Lu, L.; He, D.; Huang, Q.; Ke, C.; Li, Z.; et al. Serotypes, seasonal trends, and antibiotic resistance of non-typhoidal Salmonella from human patients in Guangdong Province, China, 2009-2012. BMC Infect. Dis. 2015, 15, 53. [CrossRef] [PubMed]

120. Tu, L.T.; Hoang, N.V.; Cuong, N.V.; Campbell, J.; Bryant, J.E.; Hoa, N.T.; Kiet, B.T.; Thompson, C.; Duy, D.T.; Phat, V.V.; et al. High levels of contamination and antimicrobial-resistant non-typhoidal Salmonella serovars on pig and poultry farms in the Mekong Delta of Vietnam. Epidemiol. Infect. 2015, 143, 3074-3086. [CrossRef] [PubMed]

121. Nagshetty, K.; Channappa, S.T.; Gaddad, S.M. Antimicrobial susceptibility of Salmonella typhi in India. J. Infect. Dev. Ctries 2010, 4, 70-73. [PubMed]

122. Mandal, S.; DebMandal, M.; Pal, N.K. Antibiotic Resistance of Salmonella enterica Serovar Typhi in Kolkata, India, and In Vitro Experiments on Effect of Combined Chemotherapy. Sci. World J. 2012, 2012, 454059. [CrossRef] [PubMed]

123. Adabara, N.U.; Ezugwu, B.U.; Momojimoh, A.; Madzu, A.; Hashiimu, Z.; Damisa, D. The Prevalence and Antibiotic Susceptibility Pattern of Salmonella typhi among Patients Attending a Military Hospital in Minna, Nigeria. Adv. Prev. Med. 2012, 2012, 875419. [CrossRef] [PubMed]

124. Ugboko, H.; de, N. Mechanisms of Antibiotic resistance in Salmonella typhi. Int. J. Curr. Microbiol. Appl. Sci. 2014, 3, 461-476.

125. Balcázar, J.L.; Subirats, J.; Borrego, C.M. The role of biofilms as environmental reservoirs of antibiotic resistance. Front. Microbiol. 2015, 6, 1216. [CrossRef] [PubMed]

126. Holcomb, H.G.; Durbin, K.J.; Cho, M.; Choi, K.J.; Darling, N.D.; Angerio, A.D. Ethicillin-resistant Staphylococcus aureus as a threat to public health: a cellular approach. GU J. Health Sci. 2008, 5, 2.

127. Adegoke, A.A.; Komolafe, A.O. Multidrug Resistant Staphylococcus aureus in Clinical Cases in Ile-Ife, Southwest Nigeria. Int. J. Med. Med. Sci. 2009, 1, 68-72.

128. Frieden, T.R. Maximizing infection prevention in the next decade: Defining the unacceptable. Infect. Control Hosp. Epidemiol. 2010, 31, S1-S3. [CrossRef] [PubMed]

129. Johnson, A.P. Methicillin-resistant Staphylococcus aureus: the European landscape. Antimicrob. Chemother. 2011, 66 (Suppl. S4), iv43-iv48. [CrossRef] [PubMed]

130. Neel, R. Multidrug resistance of isolates of methicillin resistant Staphylococcus aureus (MRSA) in paper currency notes from restaurants and hotels in Lusaka in Zambia. Int. J. Pharm. Pharm. Sci. 2012, 5, 363-366.

131. Adegoke, A.A.; Okoh, A.I. Species diversity and antibiotic resistance properties of Staphylococcus of farm animal origin in Nkonkobe Municipality. Folia Microbiol. 2014, 59, 133-140. [CrossRef] [PubMed]

132. Reinert, R.R.; Reinert, S.; van der Linden, M.; Cil, M.; Al-Lahham, A.; Appelbaum, P. Antimicrobial Susceptibility of Streptococcus pneumoniae in Eight European Countries from 2001 to 2003. Antimicrob. Agents Chemother. 2005, 29, 2903-2913. [CrossRef] [PubMed]

133. Dagan, R.; Klugman, K. Impact of Conjugate Pneumococcal Vaccine on Antibiotic Resistance. In Pneumococcal Vaccines; Siber, G., Klugman, K., Mäkelä, P., Eds.; ASM Press: Washington, DC, USA, 2008; pp. 369-385.

134. Vila-Corcoles, A.; Bejarano-Romero, F.; Salsench, E. Drug-resistance in Streptococcus pneumoniae isolates among Spanish middle aged and older adults with community-acquired pneumonia. BMC Infect. Dis. 2009, 9, 36. [CrossRef] [PubMed]

135. Chawla, K.; Gurung, B.; Mukhopadhyay, C.; Bairy, I. Reporting emerging resistance of Streptococcus pneumoniae from India. J. Glob. Infect. Dis. 2010, 2, 10-14. [CrossRef] [PubMed]

136. Jenkins, T.C.; Sakai, J.; Knepper, B.C.; Swartwood, C.J. Risk Factors for Drug-resistant Streptococcus pneumoniae and Antibiotic Prescribing Practices in Outpatient Community-acquired Pneumonia. Acad. Emerg. Med. 2012, 19, 703-706. [CrossRef] [PubMed] 
137. Raju, A.; Santos, E.R.; Bakota, E.V.; Yang, B.; Arafat, R.R. Susceptibility Profile of Drug-Resistant Streptococcus pneumoniae Based on ELR. ISDS 2015 Conference Abstracts Online. J. Public Health Inform. 2015, 8, e154.

138. Kim, L.; McGee, L.; Tomczyk, S.; Beall, B. Biological and epidemiological features of antibiotic-resistant Streptococcus pneumoniae in pre- and post-conjugate vaccine eras: a United States perspective. Clin. Microbiol. Rev. 2016, 29, 525-552. [CrossRef] [PubMed]

139. Zignol, M.; Dean, A.S.; Falzon, D.; van Gemert, W.; Wright, A.; van Deun, A.; Portaels, F.; Laszlo, A.; Espinal, M.A.; Pablos-Méndez, A.; et al. Twenty Years of Global Surveillance of Antituberculosis-Drug Resistance. N. Engl. J. Med. 2016, 375, 1081-1089. [CrossRef] [PubMed]

140. Udwadia, Z.F.; Amale, R.A.; Ajbani, K.K.; Rodrigues, C. Totally Drug-Resistant Tuberculosis in India. Clin. Infect. Dis. 2012, 54, 579-581. [CrossRef] [PubMed]

141. Klopper, M.; Warren, R.M.; Hayes, C.; van Pittius, N.C.G.; Streicher, E.M.; Müller, B.; Sirgel, F.A.; Mamisa, C.-N.; Hoosain, E.; Coetzee, G.; et al. Emergence and Spread of Extensively and Totally Drug-Resistant Tuberculosis, South Africa. Emerg. Infect. Dis. 2013, 19, 449-455. [CrossRef] [PubMed]

142. Velayati, A.A.; Farnia, P.; Masjedi, M.R. The totally drug resistant tuberculosis (TDR-TB). Int. J. Clin. Exp. Med. 2013, 6, 307-309. [PubMed]

143. Parida, S.K.; Axelsson-Robertson, R.; Rao, M.V.; Singh, N.; Master, I.; Lutckii, A.; Keshavjee, S.; Andersson, J.; Zumla, A.; Maeurer, M. Totally drug-resistant tuberculosis and adjunct therapies (Review). J. Intern. Med. 2015, 277, 388-405. [CrossRef] [PubMed]

144. Liu, Z.; Wang, W.; Zhu, Y.; Gong, Q.; Yu, W.; Lu, X. Antibiotics at subinhibitory concentrations improve the quorum sensing behavior of Chromobacterium violaceum. FEMS Microbiol. Lett. 2013, 341, 37-44. [CrossRef] [PubMed]

145. Subhadra, B.; Oh, M.H.; Choi, C.H. Quorum sensing in Acinetobacter: With special emphasis on antibiotic resistance, biofilm formation and quorum quenching. AIMS Microbiol. 2016, 2, 27-41.

146. Anderson, G.G.; O’Toole, G.A. Innate and Induced Resistance Mechanisms of Bacterial Biofilms. Curr. Top. Microbiol. Immunol. 2008, 322, 85-105. [PubMed]

147. Andersson, D.I.; Hughes, D. Microbiological effects of sublethal levels of antibiotics. Nat. Rev. Microbiol. 2014, 12, 465-478. [CrossRef] [PubMed]

148. Stewart, P.S.; Costerton, J.W. Antibiotic resistance of bacteria in biofilms. Lancet 2001, 358, 135-138. [CrossRef]

149. Anderl, J.N.; Franklin, M.J.; Stewart, P.S. Role of antibiotic penetration limitation in Klebsiella pneumoniae biofilm resistance to ampicillin and ciprofloxacin. Antimicrob. Agents Chemother. 2000, 44, 1818-1824. [CrossRef] [PubMed]

150. Røder, H.L.; Sørensen, S.J.; Burmølle, M. Studying bacterial multispecies biofilms: Where to start? Trends Microbiol. 2016, 24, 503-513. [CrossRef] [PubMed]

151. Weitao, T. Multicellularity of a unicellular organism in response to DNA replication stress. Res. Microbiol. 2009, 160, 87-88. [CrossRef] [PubMed]

152. Kostakioti, M.; Hadjifrangiskou, M.; Hultgren, S.J. Bacterial biofilms: development, dispersal, and therapeutic strategies in the dawn of the post antibiotic era. Cold Spring Harbor Perspect. Med. 2013, 3, a010306. [CrossRef] [PubMed]

153. Mulcahy, L.R.; Isabella, V.M.; Lewis, K. Pseudomonas aeruginosa biofilms in disease. Microb. Ecol. 2014, 68, 1-12. [CrossRef] [PubMed]

154. Singh, R.; Ray, P. Quorum sensing-mediated regulation of staphylococcal virulence and antibiotic resistance. Future Microbiol. 2014, 9, 669-681. [CrossRef] [PubMed]

155. Canton, R.; Morosini, M. Emergence and spread of antibiotic resistance following exposure to antibiotics. FEMS Microbiol. Rev. 2011, 35, 977-991. [CrossRef] [PubMed]

156. Davies, J.A.; Harrison, J.J.; Marques, L.L.; Foglia, G.R.; Stremick, C.A.; Storey, D.G.; Turner, R.J.; Olson, M.E.; Ceri, H. The GacS sensor kinase controls phenotypic reversion of small colony variants isolated from biofilms of Pseudomonas aeruginosa PA14. FEMS Microbiol. Ecol. 2007, 59, 32-46. [CrossRef] [PubMed]

157. Paraje, M.G. Antimicrobial Resistance in Biofilms. In Science Against Microbial Pathogens: Communicating Current Research and Technological Advances; Méndez-Vilas, A., Ed.; Formatex Research Center: Badajoz, Spain, 2011; pp. 736-744. 
158. Anderson, S.W.; Stapp, J.R.; Burns, J.L.; Qin, X. Characterization of small-colony-variant Stenotrophomonas maltophilia isolated from the sputum specimens of five patients with cystic fibrosis. J. Clin. Microbiol. 2007, 45, 529-535. [CrossRef] [PubMed]

159. Wright, G.D. The antibiotic resistome: the nexus of chemical and genetic diversity. Nat. Rev. Microbiol. 2007, 5, 175-186. [CrossRef] [PubMed]

160. Stenström, T.A.; Seidu, R.; Ekane, N.; Zurbrügg, C. Microbial Exposure and Health Assessments in Sanitation Technologies and Systems; EcoSanRes Series; Stockholm Environment Institute (SEI): Stockholm, Sweden, 2011.

161. Scallan, E.; Hoekstra, R.M.; Angulo, F.J.; Tauxe, R.V.; Widdowson, M.A.; Roy, S.L.; Jones, J.L.; Griffin, P.M. Foodborne illness acquired in the United States-Major pathogens. Emerg. Infect. Dis. 2011, 17, 7-15. [CrossRef] [PubMed]

162. Ashbolt, N.J.; Amezquita, A.; Backhaus, T.; Borrelio, P.; Brant, K.K.; Collignon, P.; Coors, A.; Finley, R.; Gaze, W.H.; Heberer, T.; et al. Human health risk assessment (HHRA) for environmental development and transfer of antibiotic resistance. Environ. Health Perspect. 2013, 121, 993-1001. [CrossRef] [PubMed]

163. Michael, I.; Rizzo, L.; McArdell, C.S.; Manaia, C.M.; Merlin, C.; Schwartz, T.; Dagot, C.; Fatta-Kassinos, D. Urban wastewater treatment plants as hotspots for the release of antibiotics in the environment: A review. Water Res. 2013, 47, 957-995. [CrossRef] [PubMed]

164. Shakya, R.; Thapa, P.; Saha, R.N. In vitro and in vivo evaluation of gastro retentive floating drug delivery system of ofloxacin. Asian J. Pharm. Sci. 2013, 8, 191-198. [CrossRef]

165. Ling, L.L.; Schneider, T.; Peoples, A.J.; Spurring, A.L.; Engels, I. A new antibiotic kills pathogens without detectable resistance. Nature 2015, 517, 455-459. [CrossRef] [PubMed]

166. Palombo, E.A. Traditional Medicinal Plant Extracts and Natural Products with Activity against Oral Bacteria: Potential Application in the Prevention and Treatment of Oral Diseases. Evid. Based Complement. Altern. Med. 2011, 2011, 680354. [CrossRef] [PubMed]

167. Adak, S.; Upadrasta, L.; Kumar, S.P.J.; Soni, R.; Banerjee, R. Quorum Quenching-An Alternative Antimicrobial Therapeutics. Available online: http://www.formatex.info/microbiology3/book/586--593. pdf (accessed on 11 October 2016).

168. Tang, K.; Zhang, X.H. Quorum Quenching Agents: Resources for Antivirulence Therapy. Mar. Drugs 2014, 12, 3245-3282. [CrossRef] [PubMed]

169. Bordi, C.; de Bentzmann, S. Hacking into bacterial biofilms: a new therapeutic challenge. Ann. Intensive Care 2011, 1, 19. [CrossRef] [PubMed]

170. World Health Organization. Step-by-Step Approach for Development and Implementation of Hospital Antibiotic Policy and Standard Treatment Guidelines 2011; World Health Organization: Geneva, Switzerland, 2011.

Sample Availability: Samples of the materials (journals used) are available from the authors.

(c) 2016 by the authors; licensee MDPI, Basel, Switzerland. This article is an open access article distributed under the terms and conditions of the Creative Commons Attribution (CC-BY) license (http://creativecommons.org/licenses/by/4.0/). 